\title{
ОСОБЛИВОСТІ ФОРМУВАННЯ КОРПОРАТИВНИХ ОСОБИСТІСНИХ ЯКОСТЕЙ СТУДЕНТІВ ЗАСОБАМИ ФІЗИЧНОГО ВИХОВАННЯ
}

Ковалевський С. В., Кошева Л. В. Особливості формування корпоративних особистісних якостей студентів засобами фізичного виховання.

У статті розкрито особливості процесу формування особистісних якостей студента в контексті корпоративної культури, яка є основною складником, що дозволяє організації бути успішною в умовах ринкових відносин. Висвітлено шляхи формування корпоративних якостей студентів як майбутніх випускників, орієнтованих на ринок праці.

Ключові слова: особистісні якості студентів, педагогічні технології, корпоративна культура, системний підхід, виховний процес, фізичне виховання.

Ковалевский С. В., Кошевая Л. В. Особенности формирования корпоративных личностных качеств студентов средствами физического воспитания.

В статье раскрыты особенности процесса формирования личностных качеств студентов средствами физического воспитания в контексте корпоративной культуры, которая является основным фактором, позволяющим организации быть успешной в условиях рыночных отношений. Раскрыты пути формирования корпоративных качеств студентов как будущих выпускников, ориентированных на рынок труда.

Ключевые слова: личностные качества студентов, педагогические технологии, корпоративная культура, системный подход, воспитательный процесс, физическое воспитание.

Kowalewski P. V., Koshevaya L. V. Osobennosti formings of corporate personality qualities of students by facilities of physical education.

In the article the features of process of forming of personality qualities of students are presented by facilities of physical education in the context of corporate culture. Being a sustems factor, a corporate culture of any organization is a basic constituent, that allows organization to be successful in the conditions of market relations. The ways of forming of corporate qualities of students are rotined as future graduating students, oriented to the market of labour.

Key words: personality qualities of students, pedagogical technologies, corporate culture, approach of the systems, educate process, physical education.

Одним із важливих завдань вищого навчального закладу є адаптація його випускників до вимог роботодавців в умовах ринкових відносин. Адаптація передбачає як високий рівень професійної підготовки, так і формування системи особистісних якостей студента, здатного відповідати організаційній культурі підприємства, що налаштовує його співробітників на максимальний результат. Система формування особистісних якостей студента базується на основі педагогічних технологій, орієнтованих на успішну їх реалізацію у навчально-виховному процесі.

Найбільшою мірою таке поєднання пов'язують із феноменом корпоративної культури, під якою звичайно розуміють комплекс найбільш важливих положень, прийнятих членами організації, і таких, що виявляються у цінностях, які заявляються організацією й задають людям орієнтири їхньої поведінки та дій.

Метою статті є розв'язання суперечності між об'єктивною потребою сучасних підприємств у фахівцях із високим рівнем корпоративної культури і недостатністю розроблення науково-методичного забезпечення освітнього процесу технологіями іï формування у студентів вищих технічних навчальних закладів. 
Процес формування корпоративної культури студента вищого технічного навчального закладу змістовно повинен розглядатися як робота 3 формування системи певних цінностей, як прийнятих молодим фахівцем, так і таких, що декларуються підприємствомроботодавцем. Більшість дослідників корпоративної культури посилаються на неусвідомлювані базові припущення, які визначають зміст іiі ключових елементів. Відсутність здатності випускника вищого навчального закладу сприймати принципи корпоративної культури підприємства-роботодавця й відповідати їм із початку своєї трудової діяльності зумовлює виникнення значних труднощів у процесі його адаптації до практичної діяльності в ринкових умовах $[1 ; 2]$.

Найважливішим чинником цільового формування системи цінностей у структурі особистісних якостей студента стає певне поєднання засобів і методів його фізичного виховання. Однак у контексті корпоративної культури цей чинник вивчений недостатньою мірою.

Культура особистості впливає на мотиваційно-цільову сферу. Саме ії високий рівень сформованості має вплив на комплекс позитивних внутрішніх мотивів і спонукає студентів успішно навчатися, оскільки високий рівень навчальної мотивації $є$ одним із найбільш дієвих засобів підвищення ефективності і якості навчального процесу.

Вимоги до особистісних якостей студентів вищих технічних навчальних закладів засновані на необхідності розвивати лідерство, комунікативність, командний дух, здатність учитися.

Педагогічна складова формування особистості студента полягає в необхідності ефективного здійснення процесу навчальної діяльності,задля чого потрібно навчитися користуватися сучасними педагогічними технологіями так, щоб ураховувалися індивідуальні особливості тих, кого навчають, індивідуальний підхід до підготовки фахівців із урахуванням принципів корпоративної культури кожної фірми-роботодавця. Потрібно брати до уваги ту обставину, що гармонійний педагогічний процес можливий тільки як точне відтворення заздалегідь спроектованої педагогічної технології [4].

Пропонуючи технологію формування особистісних якостей студентів як майбутніх фахівців, варто виокремити іiі основні ознаки: послідовність елементів (стратегій) формує процес зміни показників, що характеризують особистісні якості студентів. Цей процес фактично $\epsilon$ «переведенням» об’єкта - студента першого курсу - 3 комплексом якостей Х0 у комплекс якостей X1 на старшому курсі [5].

Особливої уваги набув процес формування корпоративної культури студентів і довкілля - вищого навчального закладу. У процесі реалізації педагогічних технологій викладачам вищої школи необхідно забезпечити формування таких особистісних якостей випускника вищого навчального закладу, які дозволили б сформувати систему його устремлінь і цінностей, що дозволить йому «увійти» до сформованої у фірмі корпоративної культури співробітників, а також адаптуватися до вимог зміни організаційної культури фірми.

Значимість корпоративної культури студентської спільноти ВНЗ полягає в тому, що вона дозволяє без адміністративного тиску відбирати найбільш ефективні моделі поведінки студентів, сприяє розвитку творчого й активного студента, орієнтованого у своїй життєдіяльності не тільки на власні досягнення, але й на загальний успіх оточуючих його людей і співтовариств.

Специфічні особливості формування корпоративної культури студентів у системі фізичного виховання полягають у тому, що з позицій методологічного підходу основним шляхом формування сукупності особистісних цінностей студентів є їхнє виховання в процесі різних видів діяльності, спрямованої на їх духовне, інтелектуальне й фізичне вдосконалення.

Педагогічна технологія формування фізичної культури особистості повинна мати всі ознаки технологічної системи. У межах такого підходу повинен розглядатися процес послідовного переходу від однієї стратегії до іншої, що забезпечує покращення фізичних 
та особистісних якостей студентів, доповнюючи зміст цих стратегій самостійною роботою студентів, здобуттям ними знань і підвищенням рівня їхньої орієнтації на загальні цінності майбутньої фірми-роботодавця.

Основні принципи фізичного виховання, на яких здійснюється процес формування корпоративної культури у студентів: методологічні принципи, засновані на основній гіпотезі взаємозв'язку особистісних якостей фахівця й рівня його фізичної культури, що перебувають у системному зв'язку з іншими професійними якостями фахівця; методичні принципи, що враховують засоби досягнення вищевказаної мети; операційні принципи, що враховують витрати й результат, що досягається при цьому, у кількісному вираженні.

На основі теоретико-методологічного аналізу формування корпоративної культури у вищому технічному навчальному закладі нами розроблено концептуальну модель фахівця, підготовка якого здійснюється у вищому навчальному закладі. Ця модель містить чотири основні блоки-моделі: модель особистості студента, модель процесу підготовки фахівця, модель конкурентоздатності фахівця та модель корпоративної культури організації [6].

У процесі формування фахівця найважливіше значення мають виховна діяльність i психолого-педагогічна підтримка розвитку особистості. Саме ці складникиі особистісної підсистеми моделі процесу підготовки фахівця позначені в моделі діяльності: перелік галузей, об'єктів, видів професійної діяльності, розв'язуваних завдань і необхідних компетенцій. Система формованих цінностей $є$ визначальною умовою досягнення необхідних професійних якостей фахівця.

При цьому компетентнісна складова моделі діяльності перебуває в тісному взаємозв'язку з характеристикою зовнішнього середовища моделі корпоративної культури організації. У цьому випадку організація є замовником фахівця, висуваючи до нього систему вимог до компетенцій.

Отже, існує можливість управління мотиваційно-ціннісним ставленням студентів до корпоративної культури засобами фізичної культури задля досягнення потрібного у професійній діяльності набору особистісних якостей фахівця. Задля цього потрібні: вихідне діагностування, принципи й технології реалізації мотивів і цінностей учасників навчального процесу, включаючи емоційне підкріплення на навчальних або секційних заняттях у студентських групах.

Самооцінка способу життя на основі трудових цінностей студента й засобів фізичного виховання стає центром формування конкурентоздатності студента (рис. 1).

На першому, аналітико-констатувальному, етапі здійснюється аналіз навчальних програм, підручників, методичних і навчальних посібників із фізичного виховання 3 метою вивчення стану формування корпоративної культури вітчизняними й зарубіжними авторами, визначаються критерії оцінки та оцінювання рівня сформованості корпоративної культури студентів.

На пошуковому етапі проведення дослідження нами було розроблено методичну систему формування корпоративної культури студентів вищого технічного навчального закладу засобами фізичного виховання, визначалися дидактичні умови іiі реалізації, готувались експериментальні матеріали для студентів і викладачів кафедри фізичного виховання.

На формувальному етапі здійснювалась апробація експериментальної методики та відбувалось обговорення результатів на науково-технічних конференціях. Здійснювався аналіз одержаних даних, систематизувались і статистично оброблялися результати експерименту. Розроблялися методичні рекомендації для викладачів вищого навчального закладу.

Дослідно-експериментальна робота здійснювалась у Донбаській державній машинобудівній академії.

На основі здійсненого аналізу сутності корпоративної культури студентської спільноти, а також системного впливу фізичного виховання на ціннісно-мотиваційні ознаки 
студентів було визначено критерії та виокремлено показники, що дозволяють визначити рівень сформованості корпоративної культури.

Рівні показника корпоративної культури визначались як «низький», коли показник корпоративної культурі перебував у межах 0-8, «середній»- більший ніж 8 і досягав 16; «високий» - рівень показника корпоративної культури більший, ніж 16. Максимальний можливий рівень показника може досягнути 24.

\begin{tabular}{|c|c|}
\hline Трудові цінності & \multirow{2}{*}{$\begin{array}{l}\text { Потреби, що викликають } \\
\text { мотивацію праці }\end{array}$} \\
\hline Можливість досягнення досконалості & \\
\hline в навчанні і майбутній роботі & Самоактуалізації \\
\hline Можливість отримання знань і & Пораг \\
\hline \multirow{3}{*}{$\begin{array}{l}\text { Відповідність навчання, } \\
\text { а в подальшому - роботи, } \\
\text { здібностям студента }\end{array}$} & \\
\hline & Соціальні \\
\hline & \multirow[t]{2}{*}{ Безпеки i } \\
\hline Можливість творчості & \\
\hline Можливість самореалізації & Фізіологічні \\
\hline $\begin{array}{l}\text { Можливість участі в управлінні } \\
\text { академією, групою тощо. }\end{array}$ & $\frac{\downarrow}{\text { Самооцінка способу життя }}$ \\
\hline Можливість досягнути чогось & $\begin{array}{l}\text { Чинники, що сприяють } \\
\text { формуванню }\end{array}$ \\
\hline $\begin{array}{l}\text { Можливість юридичного } \\
\text { оформлення } \\
\text { більш високого статусу - }\end{array}$ & $\begin{array}{c}\text { формуванню } \\
\\
\end{array}$ \\
\hline $\begin{array}{c}\text { Забезпечення надійного } \\
\text { майбутнього, }\end{array}$ & $\begin{array}{l}\text { Засоби фізичного виховання } \\
\text { За ознакою систем }\end{array}$ \\
\hline $\begin{array}{c}\text { Відсутність жорстких рамок, } \\
\text { грубого тиску, можливість самому }\end{array}$ & $\begin{array}{l}\text { За ознакою переважної } \\
\text { спрямованості }\end{array}$ \\
\hline Відсутність перевантажень і & За біомеханічними \\
\hline 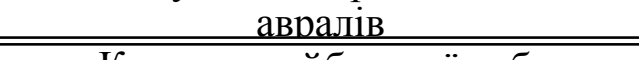 & \multirow{2}{*}{$\begin{array}{r}\text { За ознакою } \\
\text { фізіологічних }\end{array}$} \\
\hline Користь майбутньої роботи & \\
\hline Справедливість в оцінці знань & $\begin{array}{c}\text { За ознакою спортивної } \\
\text { спеціалізації }\end{array}$ \\
\hline $\begin{array}{c}\text { Цікаве навчання, } \\
\text { ав полапышому - nобота }\end{array}$ & \multirow{2}{*}{$\begin{array}{r}\text { За ознакою } \\
\text { використання } \\
\end{array}$} \\
\hline Успіх, визнаний іншими & \\
\hline 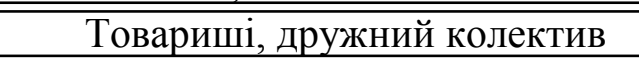 & \multirow{2}{*}{\begin{tabular}{|c|} 
За ознакою \\
використання оздоровчих
\end{tabular}} \\
\hline "Високий заробіток на майбутній & \\
\hline
\end{tabular}

Рис. 1. Модель особистості студента

Для проведення формувального етапу експерименту були залучені, як i на попередньому - констатувальному - студенти двох факультетів: інженерно-економічного й інженерної механіки.

Навчальний процес із фізичного виховання в контрольних групах (факультет інженерної механіки) проводився згідно зі звичайними робочими програми, а для студентів експериментальних груп (інженерно-економічний факультет) було розроблено нові методики із застосуванням найбільш впливових засобів і методів фізичного виховання, створено всі умови з урахуванням організаційних особливостей студентського спорту та надано можливість для позаурочних занять у спортивних секціях, абонементних групах і у фітнес-центрі академії 
Порівняльний аналіз динаміки рівнів сформованості корпоративної культури студентів вищих технічних навчальних закладів довів зростання високого рівня корпоративної культури у групах студентів, у яких були запропоновані та застосовані засоби фізичного виховання за інтересами студентів, склало понад $20 \%$. Це свідчить про те, що вимоги ринку праці до майбутнього молодого фахівця підвищувати частку «високого» рівня показника корпоративної культури можуть бути успішно виконані засобами фізичного виховання, що підтверджено результатами нашого дослідження у формувальному експерименті (табл. 1).

Сукупність отриманих результатів у динаміці за проміжок часу дозволила зафіксувати зміни у рівнях як корпоративної культури, так і особистісних якостей студентів, що надає змогу зробити висновок про вплив засобів фізичного виховання на особистісні якості фахівців з точки зору корпоративної культури.

Таблиия 1

Результати формувального експерименту

\begin{tabular}{|l|c|c|c|c|}
\hline \multirow{2}{*}{$\begin{array}{c}\text { Рівні сформованості } \\
\text { корпоративної культури }\end{array}$} & \multicolumn{2}{|c|}{$\begin{array}{c}\text { Констатувальний } \\
\text { експеримент }\end{array}$} & \multicolumn{2}{|c|}{$\begin{array}{c}\text { Формувальний } \\
\text { експеримент }\end{array}$} \\
\cline { 2 - 5 } & КГ & $\mathrm{E} \Gamma$ & КГ & $\mathrm{E}$ \\
\hline Низький & $30,23 \%$ & $31,67 \%$ & $20,28 \%$ & $10,90 \%$ \\
\hline Середній & $64,19 \%$ & $65,16 \%$ & $74,53 \%$ & $63,98 \%$ \\
\hline Високий & $5,58 \%$ & $3,17 \%$ & $5,19 \%$ & $25,12 \%$ \\
\hline
\end{tabular}

Все викладене надало підставу припустити, що майже всі показники тестування студентів молодших курсів відрізняються від показників тестування студентів старших курсів. 3 огляду на комплекс навчальних занять, що формують загальну технологію навчання в системі фізичного виховання в технічному вищому навчальному закладі, можна простежити зміни значущості чинників фізичного виховання й формованих цінностей як вияви особистісних якостей студентів від курсу до курсу. Для визначення тактики і стратегії експериментальної роботи важливо було встановити тенденцію вікової зміни показників різних якостей і їхніх взаємозв'язків.

Сукупність чинників із вказівкою ступеня їхньої значимості практично формує модель управління особистісними якостями студентів у процесі їхнього навчання у вищому навчальному закладі.

Результати дослідження свідчать про досягнення мети і виконання поставлених завдань.

У результаті дослідження уточнено поняття сутності і структури корпоративної культури в контексті системи цінностей уструктурі особистісних якостей студента вищого технічного навчального закладу. Змістовно процес формування корпоративної культури студента повинен розглядатися як робота 3 формування системи певних цінностей, прийнятих як молодим фахівцем, так і декларованих підприємством-роботодавцем.

Встановлено, що врахування індивідуальних особливостей та інтересів студентів, розв'язання оздоровчих i освітньо-виховних завдань, різноманітність, новизна, емоційність занять, а також загальнокультурний рівень, ерудиція, наукова й методична підготовка, відповідальність, працьовитість, переконаність, розумна вимогливість, педагогічна майстерність викладача $\epsilon$ основними умовами, що забезпечують якість виховного процесу.

Характеристиками особистості, що визначають іiі світогляд, життєву спрямованість, суспільну поведінку, основні тенденції розвитку є статус і соціальні функції, мотивація поведінки й ціннісні орієнтації, структура й динаміка стосунків.

Необхідним $є$ системне виявлення мотивації студентів, використання фізичного виховання для розуміння іï особистісної значимості, а також можливості трансформації прикладної фізичної культури в професійні якості фахівця з вищою освітою, здатного 
відповідати корпоративній культурі організації-роботодавця. Оцінка ступеня досягнення результатів щодо формування необхідних компетенцій веде до необхідності своєчасної корекції технології освітньої діяльності.

Опис сукупності формованих особистісних якостей студента або вже сформованих якостей фахівця становить слабко формалізоване завдання. Моделювання як засіб формалізації й подальшого використання для розв'язання поставлених завдань дозволяє досягти необхідного рівня якості вирішення таких завдань.

Протягом реалізації обговорюваної педагогічної технології формувалося усвідомлене активне ставлення до фізичної культури: різні «траєкторії» розвитку мотиваційноціннісного потенціалу студентів; зростання кількості чинників, що характеризують особистісні властивості студентів і їхній мотиваційно-ціннісний потенціал; вплив педагогічних технологій та умов на ефективність формування особистісних якостей студентів. Особливо ефективним, на нашу думку, є впровадження в практику підготовки студентів комплексу фітнес-програм, спрямованих на комплексне досягнення показників фізичного розвитку й духовного рівня суб'єктів корпоративних стосунків у колективі. Зростання високого рівня корпоративної культури у групах студентів, де були запропоновані та застосовані засоби фізичного виховання за інтересами студентів, склало понад 20 \%, що свідчить про те, що вимоги ринку праці до майбутнього молодого фахівця підвищувати частку «високого» рівня показника корпоративної культури можуть бути успішно виконані, що підтверджено результатами дослідження.

Проведене дослідження не вичерпує всіх багатоаспектних проблем корпоративної культури і процесу iї формування у студентів вищих технічних навчальних закладів. Потребує спеціального дослідження питання: створення системи комплексного виховання студентів на основі багатомірних зв'язків актуальних рівнів розвитку особистості; подальшого розроблення нової теорії комплексного формування особистості фахівця, здатного бути конкурентоспроможним в умовах динамічних перетворень виробництва; міждисциплінарного застосування теорії комплексного формування особистості студентів.

\section{Література}

1. Ковалевский С. В. Корпоративная культура как среда формирования системы ценностей студента и выпускника вуза / С.В.Ковалевский // Корпоративна культура організацій XXI століття :[ зб. наук. праць] / за заг. ред. С. В. Ковалевського. - Краматорськ : ДДМА, 2006. - С. 8 11. 2. Корпоративна культура : [навч. посіб.] / Г. Л. Хаєт, О. Л. Сськов, С. В. Ковалевський [та ін.] ; за заг. ред. Г. Л. Хаєта. - К. : Центр навчальної літератури, 2003. - 404 с. 3. Кошева Л. В. Формування особистісних властивостей студентів засобами фізичного виховання : [навчальний посібник для викладачів з фізичного виховання] / Л. В. Кошева. - Краматорськ : ДДМА, 2008. 96 с. 4. Кошева Л. В. Ресурси системного підходу у фізичному вихованні майбутніх фахівців у вищій школі / Л. В. Кошева // Педагогіка, психологія та медико-біологічні проблеми фізичного виховання і спорту : [наукова монографія] / за редакцією проф. Срмакова С. С. - Харків : ХДАДМ(ХХПІ), 2007. - № 11. - С. 139-143. 5. Медведева О. А. Новый подход к преподаванию основ корпоративной культуры в вузе / О. А. Медведева , Р. Ф. Суровцева // Корпоративна культура організацій XXI століття : [зб. наук. праць] / за заг. ред. С. В. Ковалевського. - Краматорськ : ДДМА, 2010. - С. 138-142. 6. Халитова И. С. Вуз как среда формирования корпоративной культуры будущих инженеров / И. С. Халитова // Образование и саморазвитие. - 2007. - № 6. - С. $106-113$. 